\title{
High Tunnel versus Climate-controlled Greenhouse: Transplant Time and Production Environment Impact Growth and Morphology of Cold-tolerant Bedding Plants
}

\author{
Joshua R. Gerovac and Roberto G. Lopez ${ }^{1,2}$ \\ Department of Horticulture and Landscape Architecture, Purdue University, \\ West Lafayette, IN 47907
}

Neil S. Mattson

School of Integrative Plant Science, Horticulture Section, Cornell University, Ithaca, NY 14853

Additional index words. average daily temperature, daily light integral, dianthus, floriculture crops, hoop house, petunia, protected cultivation, snapdragon

\begin{abstract}
Commercial bedding plant production in northern latitudes often begins in late winter and continues through spring, when average outdoor temperatures require growers to actively heat their greenhouses (GHs). High tunnels (HTs) offer energy savings as they are passively heated and cooled structures that have a low initial cost. As a result, they have been used in northern latitudes to advance and extend the growing season and improve the quality of high-value horticultural crops. However, there is limited published information on growing bedding plants in HTs in northern latitudes. Our objectives were to quantify the effects of transplant date in an HT with or without a rowcover (RC) compared with a traditional heated GH on the growth and morphology of three cold-tolerant bedding plant species at two northern latitude locations, Purdue University (Purdue) and Cornell University (Cornell). Seedlings of snapdragon (Antirrhinum majus L. 'Liberty Classic Yellow'), dianthus (Dianthus chinensis L. 'Telstar Crimson'), and petunia (Petunia Xhybrida Vilm.-Andr. 'Wave Pink') were transplanted on weeks 13, 14, and 15 in 2012 (Purdue) and 2013 (both locations) and moved to either a glass-glazed GH or an HT without (HT) or with a rowcover $(\mathrm{HT}+\mathrm{RC})$. Several quality measurements increased when plants were grown in the HT compared with those grown in the GH. Dianthus and petunia transplanted at Purdue during week 13 in the $\mathrm{HT}$ and $\mathrm{HT}+\mathrm{RC}$ were $33 \%$ and $47 \%$ shorter and had $51 \%$ and $31 \%$ more visible buds, respectively, compared with those grown in the GH. Similarly, petunia transplanted at Cornell during week 13 in the HT and HT+RC were $45 \%$ and $43 \%$ shorter, respectively, than their GH counterparts. The shoot dry mass of dianthus and snapdragon at Purdue was significantly higher when grown in the HT compared with the GH, regardless of transplant week or the use of RC likely because of increased daily light integral (DLI) in the HT environment. There was about a 1-week delay from transplant to first open flower for week 13 dianthus (at Purdue) and petunia (at both locations) when finished in the HT or HT $+R C$ vs. their GH counterparts. Such a delay would be acceptable to growers who want to reduce the use of chemical growth regulators and heating costs. However, at both locations snapdragon transplanted on week 13 to the HT or HT+RC environments were delayed by 22 to 26 days compared with the GH. A delay of over 3 weeks could interfere with a grower's production schedule, possibly making this crop unsuitable for production in northern latitude HTs.
\end{abstract}

Annual bedding plants are the most valuable sector of the commercial floriculture industry, accounting for $62 \%$ of the reported wholesale value of $\$ 5.9$ billion in the United States (USDA, 2014). Commercial GH production in northern latitudes begins in late winter and continues through spring, when the crops are marketed to consumers. In temperate climates, outdoor temperatures during production necessitate protected cultivation with active heating to prevent crops from freezing and to ensure that growers meet specific market dates. However, with the relatively volatile prices for propane, heating oil, and natural gas during the last decade, heating now accounts for $10 \%$ to $30 \%$ of the total operating costs for commercial GHs (Brumfield, 2009; EIA, 2014; Langton et al., 2006). To reduce costs associated with heating, growers have installed thermal energy curtains, increased insulation, switched to alternative fuel sources, and purchased energy-efficient heaters (Blanchard and Runkle, 2011a). Some growers in northern latitudes are starting to grow bedding plants in HTs to further reduce or eliminate heating costs (Steve Hood, personal communication). Additionally, HTs can provide warmer day temperatures and protection from rain as compared with plants growing in an outdoor environment. However, there is limited published information regarding bedding plant production in HTs.

A HT typically is a single-layer, polyethylenecovered structure that lacks automated ventilation, is heated by solar radiation, and is cooled through side or end walls that are manually opened and closed (Lamont, 2009). They are primarily used in temperate northern latitudes to extend the production season and improve the quality of high-value horticultural crops, including vegetables, fruits, and cut flowers (Hunter et al., 2012; Knewtson et al., 2010; Lamont, 2005; Ortiz et al., 2012; Rowley et al., 2010). Additionally, they are used in temperate and tropical regions of the world to exclude rain from crops, which reduces disease pressure and crop loss (Lamont, 2009). Recent research has shown that growers can use HTs to reduce or eliminate heating costs associated with finishing cold-tolerant bedding plants in northern latitudes (Currey et al., 2014).

Greenhouse growers use average daily temperature (ADT) to predict when crops will be marketable (Blanchard and Runkle, 2011a). It is well documented that temperature controls the rate of plant development, including time to unfold a leaf and time to first open flower (Adams et al., 1998; Kaczperski et al., 1991; Roberts and Summerfield, 1987). Plant development is zero at or below a species-specific base temperature $\left(T_{b}\right)$. As temperatures increase above $T_{b}$, the rate of development increases until the optimum temperature $\left(\mathrm{T}_{\mathrm{o}}\right)$ is reached. For many crops, the development rate increases nearly linearly with ADT between $T_{b}$ and $T_{o}$ (Blanchard and Runkle, 2011a; Roberts and Summerfield, 1987). This linear relationship enables growers to predict when crops will be marketable based on the ADT. Consequently, a grower's ability to predict when their crops will be ready for market is not possible in an HT due to lack of temperature control. Notwithstanding this limitation, in some situations, the energy savings of reduced or no heating associated with HT bedding plant production can still outweigh the ability to schedule crops for specific market dates (Currey et al., 2014).

A comparison of finishing spring bedding plants transplanted during week 14 in HTs to a GH revealed that dianthus (D. chinensis), petunia (Petunia $\times$ hybrida), and pansy (Viola $\times$ cornuta) could be produced in an HT with little to no delay in time to flower. For example, dianthus, petunia, and pansy grown in an HT were delayed by as few as 4,4 , and $0 \mathrm{~d}$, respectively, compared with a GH (Currey et al., 2014). However, a $-6{ }^{\circ} \mathrm{C}$ night resulted in the death of several cold-sensitive and coldintermediate species. This revealed the potential risk associated with the production of spring bedding plants in HTs. Since several cold-tolerant species survived the cold night and were only slightly delayed in flowering time, we investigated the effects of transplant week to determine if earlier transplant times were possible. To our knowledge, no work has been performed to determine the effects of early-season transplant (weeks 13 to 15 ) of 
cold-tolerant bedding plants in unheated HTs located in temperate northern latitudes. Also, we postulated that a RC could reduce the impact of low temperatures, as demonstrated by Currey et al. (2014). Therefore, the objectives of this study were to quantify the effect of three transplant dates in two northern latitudes, the use of a RC, and holding plants in a heated $\mathrm{GH}$ before moving them to an HT on the growth and development of three cold-tolerant bedding plant species.

\section{Materials and Methods}

\section{Expt. 1}

Plant material and culture. Seedlings of snapdragon (A. majus L. 'Liberty Classic Yellow'), dianthus (D. chinensis L. 'Telstar Crimson'), and petunia (Petunia $\times$ hybrida Vilm.-Andr. 'Wave Pink') in 288-cell (6-ml individual cell volume) plug trays were obtained from a commercial GH propagator (C. Raker and Sons, Litchfield, MI). The plant material was received at Purdue University (Purdue) in West Lafayette, IN (40 ${ }^{\circ} \mathrm{N}$ latitude) in 2012 on 27 Mar. (week 13), 3 Apr. (week 14), and 10 Apr. (week 15) and in 2013 at both Purdue and Cornell University [Cornell, Ithaca, NY ( $42^{\circ} \mathrm{N}$ latitude)] on 28 Mar. (week 13), 4 Apr. (week 14), and 11 Apr. (week 15). The experiments at Purdue and Cornell are denoted as Expts. 1A and 1B, respectively. On each receiving date, 21 seedlings of each species were transplanted into 10 -cm-diameter $(480 \mathrm{~mL})$ round containers filled with a commercial soilless medium comprised of (by vol.) $65 \%$ peat, $20 \%$ perlite, and $15 \%$ vermiculite (Fafard 2; Fafard, Inc., Agawam, MA). Plants were hand irrigated as necessary with water supplemented with water-soluble fertilizer (Peters Excel ${ }^{\odot} 21-5$ 20; Everris NA Inc., Marysville, $\mathrm{OH}$ ) to provide (in $\mathrm{mg} \cdot \mathrm{L}^{-1}$ ) 200 nitrogen $(\mathrm{N}), 26$ phosphorus $(\mathrm{P}), 163$ potassium $(\mathrm{K}), 1.0$ iron $(\mathrm{Fe})$, 0.5 manganese $(\mathrm{Mn})$ and zinc $(\mathrm{Zn}), 0.24$ boron (B) and copper $(\mathrm{Cu})$, and 0.1 molybdenum

\footnotetext{
Received for publication 8 Jan. 2015. Accepted for publication 15 Apr. 2015

We gratefully acknowledge Jenna Buschkoetter, Rob Eddy, Dan Hahn, Alyssa Hilligoss, Camille Mahan, Tyler Mason, Bryce Patz, Wesley Randall, and Timothy Putzke for greenhouse and laboratory assistance; Christopher Currey for statistical analysis assistance; C. Raker and Sons for plant material; Sun Gro Horticulture for substrate; Everris NA Inc. for fertilizer; Indiana Specialty Crop Block Grant 205749, United States Department of Agriculture (USDA) National Institute of Food and Agriculture (NIFA), and Multistate Hatch project NE-1335 (accession number 1001868) for support. Any opinions, findings, conclusions, or recommendations expressed in this publication are those of the author(s) and do not necessarily reflect the view of the USDA or NIFA. The use of trade names in this publication does not imply endorsement by Purdue University or Cornell University of products named nor criticism of similar ones not mentioned.

${ }^{1}$ Associate Professor and Extension Specialist.

${ }^{2}$ To whom reprint requests should be addressed; e-mailrglopez@purdue.edu.
}

(Mo). At Purdue irrigation water was supplemented with $93 \%$ sulfuric acid (Ulrich Chemical, Indianapolis, IN) at $0.08 \mathrm{mg} \cdot \mathrm{L}^{-1}$ to reduce alkalinity to $\approx 100 \mathrm{mg} \cdot \mathrm{L}^{-1}$. At Cornell, no acid supplementation was used, tap water alkalinity was $\approx 115 \mathrm{mg} \cdot \mathrm{L}^{-1}$.

Greenhouse environment. Seven plants of each species were randomly selected during each transplant week, spaced equally in trays, and placed on benches located in a glassglazed GH under natural photoperiods and a constant air temperature set point of $21^{\circ} \mathrm{C}$. Temperature was maintained with exhaust fan and evaporative-pad cooling, radiant hotwater heating, and retractable shade curtains controlled by environmental computers (Maximizer Precision 10; Priva Computers Inc., Vineland Station, Ontario, Canada) and (Operator Program; Argus Control Systems, White Rock, British Colombia, Canada) at Purdue and Cornell, respectively.

High tunnel environment. Seven plants of each species were randomly selected during each transplant week, spaced equally in trays, and placed in an HT on top of a layer of landscape fabric. At Purdue, the east-westoriented HT $(14.6 \times 7.9 \times 3.7 \mathrm{~m}$ high $)$ had a triple galvanized structural steel frame (FarmTek, Dyersville, IA) and 6-mm SunMaster polyethylene film containing copolymer resin with trilayer construction and ultraviolet additives (Lumite, Baldwin, GA) and was located in Lafayette, Indiana $\left(40^{\circ} \mathrm{N}\right)$. At Cornell, the east-west oriented HT $(29.3 \times$ $9.1 \times 4.6 \mathrm{~m}$ high, Rimol Greenhouse Systems, Hooksett, NH) was glazed with a 6-mm clear ultraviolet-treated polyethylene film. At both locations, the HT was split into two production environments: one with a rowcover $(\mathrm{HT}+\mathrm{RC})$ and another without a rowcover (HT). At Purdue, end-wall peak vents, endwall doors, and roll-up side walls were opened or closed manually to moderate temperature swings. End-wall peak vents were opened when the forecast high was $>13{ }^{\circ} \mathrm{C}$, end-wall vents and doors were opened when the forecast high was $>21^{\circ} \mathrm{C}$, and vents, doors, and roll-up side walls were opened when the forecast high was $>24{ }^{\circ} \mathrm{C}$. All ventilation was closed during periods of high winds and/or low temperatures. At Cornell, side wall ventilation was thermostat-controlled using a batterypowered motor to roll up side walls (to a $1.2 \mathrm{~m}$ height) when temperature inside the HT was above $29{ }^{\circ} \mathrm{C}$ or roll down when HT temperature fell below $18{ }^{\circ} \mathrm{C}$. In addition, end-wall peak vents and doors were manually opened in mid-to-late spring when outdoor day temperatures greater than $21{ }^{\circ} \mathrm{C}$ were anticipated. On nights when the forecast low was $<3$ or $<5{ }^{\circ} \mathrm{C}$, a high-density polyethylene fabric RC (Coverton Pro 19 floating rowcover; Fiberweb, London, UK) or (Agribon+ AG-19; Agribon, San Luis Potosi, Mexico) was pulled over a $45-\mathrm{cm}$-tall frame made of PVC at Purdue and Cornell, respectively, with the other half of the plants not being covered with fabric. At Cornell, when subsequent outdoor day temperatures were forecast to be $<12{ }^{\circ} \mathrm{C}$ the $\mathrm{RC}$ was kept on during the day.

\section{Expt. 2}

This experiment used the same plant material, cultural practices, and production environments described in Expt. 1. Twentyeight seedlings of each species were transplanted in the GH on 28 Mar. 2013 (week 13) at both Purdue (Expt. 2A) and Cornell (Expt. 2B). Seven plants remained in the GH for the duration of the experiment with the remaining plants being moved to the HT on 28 Mar. (week 13), 4 Apr. (week 14), and 11 Apr. 2013 (week 15) after being held in the $\mathrm{GH}$ environment for 0,1 , and 2 weeks, respectively.

Environmental data collection. At Purdue, HT air temperature and light intensity were measured at 20-s intervals with an enclosed thermocouple and quantum sensor, respectively, placed at plant height (WatchDog Model 2475 Plant Growth Station; Spectrum Technologies, Inc., Plainfield, IL). Air temperature in the Purdue GH was monitored and recorded with the Priva environmental computer. Two quantum sensors (Model SQ212; Apogee Instruments, Inc., Logan, UT) placed at plant height measured light intensity every $30 \mathrm{~s}$ and the average of each sensor was logged every $15 \mathrm{~min}$ by a data logger (Watch$\operatorname{dog} 2800$ Weather Station, Spectrum Technologies). A conversion factor was calculated to calibrate the quantum sensors used in the HT to those used in the GH. At Cornell, HT air temperature and light intensity were measured at 60-s intervals with an enclosed thermocouple and quantum sensor and averaged and logged every $10 \mathrm{~min}$ by a data logger (HOBO U12-012; Onset Computer Corp., Bourne, MA) placed at plant height. In the $\mathrm{GH}$ at Cornell, line quantum sensors (SQ-316, Apogee Instruments, Inc., Logan, UT) were placed at plant height to record light intensity. Air temperature and light intensity were recorded every $10 \mathrm{~s}$ and averages were logged every 10 min by a data-logger (CR3000; Campbell Scientific Inc., Logan, UT). Average daily, minimum, and maximum temperatures and DLI for each month of the study are reported in Tables 1 and 2.

Data collection and calculations. Plants were monitored daily and the date of first open flower was recorded to determine the number of days from transplant to flower (TTF). At flowering, stem length was measured as the distance from the medium surface to the growing tip of the longest shoot, and total visible flower buds were recorded. For snapdragon, each inflorescence was recorded as a flower. Plants were destructively harvested at the medium surface, dried in an oven at $70{ }^{\circ} \mathrm{C}$ for 1 week, and shoot dry mass was determined.

Experimental design and statistical analyses. Both experiments were laid out in a completely randomized design in a factorial arrangement. The factors for Expt. 1 were production environment (three levels) and transplant date (three levels). The factors for Expt. 2 were production environment (three levels) and weeks held in GH (three levels). Several experimental conditions were different between Purdue and Cornell, therefore, 
data were not pooled and are reported as separate experiments. At Purdue, Expt. 1A was repeated once over time for a total of two experimental runs and data were pooled across time. Effects of production environment, transplant date, and weeks held in the GH were compared by ANOVA using SAS (SAS version 9.3; SAS Institute, Cary, NC) PROC MIXED, with an additional program (Arnold M. Saxton, University of Tennessee, Knoxville, TN) that provided pairwise comparisons between treatments using Tukey's honestly significant test at $P \leq 0.05$.

\section{Results and Discussion}

Effect of production environment and $R C$ on temperature and light levels. The conventionally heated $\mathrm{GH}$ had a higher ADT than the HT, especially early in the experiment (Tables 1 and 2). For example, the ADTs in the HT and $\mathrm{HT}+\mathrm{RC}$ were $\approx 6{ }^{\circ} \mathrm{C}$ lower than in the $\mathrm{GH}$ in March and April for both years at Purdue (Table 1) and in April 2013 at Cornell (Table 2). However, the HT $+\mathrm{RC}$ maintained a higher ADT $\left(\approx 1.5^{\circ} \mathrm{C}\right)$ than in the HT alone during the months when the forecast lows were $<3{ }^{\circ} \mathrm{C}$. At Purdue, temperatures within the HT were never below $0{ }^{\circ} \mathrm{C}$ during either year of the study (Table 1). At Cornell, a temperature of $-0.8^{\circ} \mathrm{C}$ was observed in Mar. 2013, whereas the $\mathrm{HT}+\mathrm{RC}$ treatment was $1.6{ }^{\circ} \mathrm{C}$ warmer (Table 2). No symptoms of cold/chilling injury were observed in any plants, likely because cold-tolerant species were grown in this study. If temperatures had dropped even further, a temperature increase of 1 to $2{ }^{\circ} \mathrm{C}$ provided from the RC may have significantly reduced cold injury or crop losses such as those reported in an HT by Currey et al. (2014).

At Purdue, the DLI in the HT and HT + RC was nearly twice as high as in the glassglazed GH (Table 1) due to the single layer of polyethylene film and limited structural support. The Purdue GH had a significant amount of superstructure that reduced light levels. Additionally, a retractable shade curtain $(\approx 50 \%)$ was used to maintain the $\mathrm{GH}$ set point air temperatures, which also significantly reduced light levels. At Cornell, the HT DLI was only about $25 \%$ greater than the $\mathrm{GH}$ as the HT polyethylene was 9 years old. Additionally, the $\mathrm{GH}$ at Cornell had less structural shading components than the Purdue GH. The DLI in the HT+RC was somewhat reduced compared with the HT at both locations. At Purdue, the RC remained over the plants until $0900 \mathrm{HR}$, which reduced the DLI by $\approx 8 \%$ during Mar. 2012 and 2013. At Cornell, the RC was kept over the plants when cool days $\left(<12{ }^{\circ} \mathrm{C}\right)$ followed cool nights. Therefore, the $\mathrm{RC}$ was used for 3 (out of 4), 13, 4, and 1 nights in March, April, May, and June, respectively. Consequently, DLI in Cornell HT+RC was reduced by $\approx 20 \%$ compared with HT.

Effects of production environment and transplant week on finish time. Expt. 1. At Purdue, transplant week and production environment significantly influenced TTF of all species (Table 3). For instance, TTF of dianthus 
and petunia was delayed by $8 \mathrm{~d}$ in the HT and $\mathrm{HT}+\mathrm{RC}$, compared with plants in the $\mathrm{GH}$, respectively, when transplanted in late March (week 13) and by 4 and $2 \mathrm{~d}$ for petunia transplanted in early April (week 14).

At Cornell, transplant week and production environment significantly influenced TTF of petunia and snapdragon, but only transplant week affected TTF for Dianthus (Table 4). Time to flower of dianthus was not significantly affected by production environment but was delayed by 8 to $10 \mathrm{~d}$ for transplant week 13 as compared with transplant week 15 (Table 4). The delay may be due to lower DLI in both the GH and HT environments in the early spring. For example, at Cornell, petunia transplanted on week 13 , were delayed by 7 to $8 \mathrm{~d}$ when finished in the HT and $\mathrm{HT}+\mathrm{RC}$ environments as compared with the GH (Table 4). For petunia, the delay in TTF for plants in the HT was reduced by later transplants dates. At both locations, snapdragon TTF was delayed in both the HT and HT + RC when transplanted in weeks 13, 14, and 15. For transplant week 13, TTF of HT or HT + RC snapdragon was delayed by 22 to $26 \mathrm{~d}$ as compared with the GH. The delay in snapdragon TTF in the HT and HT+RC environments decreased somewhat by later transplant dates, but was still 12 to $14 \mathrm{~d}$ for transplant week 15.

Bedding plants are usually considered marketable when at least one flower or inflorescence is fully reflexed (Heins et al., 2000). As stated earlier, the rate of development increases nearly linearly as ADT increases. Petunia transplanted in weeks 13,14 , and 15 in the $\mathrm{GH}$ with an $\mathrm{ADT} \approx 21{ }^{\circ} \mathrm{C}$ and a DLI of 10 to $12 \mathrm{~mol} \cdot \mathrm{m}^{-2} \cdot \mathrm{d}^{-1}$ had a fully reflexed flower in $\approx 37 \mathrm{~d}$ (Table 3 ). Developmental rate models for petunia 'Wave Purple' and 'Bravo Blue' have been calculated to predict TTF (Blanchard et al., 2011; Vaid and Runkle, 2013). The authors reported that petunia 'Wave Purple' grown with an ADT of $21^{\circ} \mathrm{C}$ and a DLI of 10 to $12 \mathrm{~mol} \cdot \mathrm{m}^{-2} \cdot \mathrm{d}^{-1}$ would flower in $\approx 33 \mathrm{~d}$ (Blanchard et al., 2011). Vaid and Runkle (2013) reported that petunia 'Bravo Blue' grown with an ADT of $21{ }^{\circ} \mathrm{C}$ and an average DLI of $18 \mathrm{~mol} \cdot \mathrm{m}^{-2} \cdot \mathrm{d}^{-1}$ would flower in $\approx 34 \mathrm{~d}$. This validates that while there is a difference of $\approx 3 \mathrm{~d}$ between studies, our GH-grown petunia flowered near the predicted values. At Purdue, petunia transplanted in the HT in weeks 14 and 15 with ADTs of 16 and $17^{\circ} \mathrm{C}$ and a DLI of 21 and 22 $\mathrm{mol} \cdot \mathrm{m}^{-2} \cdot \mathrm{d}^{-1}$ flowered in 40 and $37 \mathrm{~d}$, respectively (Table 3). Blanchard et al. (2011) also reported that as DLI increased from 4 to 14 $\mathrm{mol} \cdot \mathrm{m}^{-2} \cdot \mathrm{d}^{-1}$, TTF of petunia 'Wave Purple' grown at an ADT of $20^{\circ} \mathrm{C}$ was reduced $12 \mathrm{~d}$. In our study, the DLI in the HT exceeded the maximum DLI presented in the Blanchard et al. (2011), which did not allow us to compare our results to their model. However, the similar TTF for petunia transplanted on week 15 in the GH and HT was likely influenced by the higher DLI in the HT.

Effects of holding in the greenhouse on finish time. Expt. 2. At both Purdue and Cornell holding dianthus in the $\mathrm{GH}$ at $21{ }^{\circ} \mathrm{C}$

Table 3. Expt. 1A Purdue University. Time to flower (TTF; days) from transplant to first open flower for dianthus, petunia, and snapdragon grown in three production environments; greenhouse (GH), high tunnel $(\mathrm{HT})$, high tunnel + rowcover $(\mathrm{HT}+\mathrm{RC})$, transplanted during weeks 13, 14, and 15. Means sharing a letter are not statistically different by Tukey's honestly significant difference test at $P \leq 0.05$.

\begin{tabular}{|c|c|c|c|}
\hline \multirow[b]{2}{*}{ Transplant week (TW) } & \multicolumn{3}{|c|}{ Production environment (PE) } \\
\hline & $\mathrm{GH}$ & HT & $\mathrm{HT}+\mathrm{RC}$ \\
\hline & \multicolumn{3}{|c|}{ Dianthus } \\
\hline Week 13 & $46 \mathrm{a}^{\mathrm{z}} \mathrm{B}^{\mathrm{y}}$ & $54 \mathrm{aA}$ & $54 \mathrm{aA}$ \\
\hline Week 14 & $46 \mathrm{aA}$ & $48 \mathrm{bA}$ & $48 \mathrm{bA}$ \\
\hline Week 15 & $43 \mathrm{aAB}$ & $43 \mathrm{cB}$ & $46 \mathrm{bA}$ \\
\hline \multicolumn{4}{|l|}{ Significance } \\
\hline TW & \multicolumn{3}{|c|}{$* * *$} \\
\hline $\mathrm{PE}$ & \multicolumn{3}{|c|}{$* * *$} \\
\hline \multirow[t]{2}{*}{$\mathrm{TW} \times \mathrm{PE}$} & \multicolumn{3}{|c|}{$* * *$} \\
\hline & \multicolumn{3}{|c|}{ Petunia } \\
\hline Week 13 & $37 \mathrm{aB}$ & $45 \mathrm{aA}$ & $45 \mathrm{aA}$ \\
\hline Week 14 & $37 \mathrm{aB}$ & $40 \mathrm{bA}$ & $39 \mathrm{bA}$ \\
\hline Week 15 & $36 \mathrm{aA}$ & $37 \mathrm{cA}$ & $38 \mathrm{bA}$ \\
\hline \multicolumn{4}{|l|}{ Significance } \\
\hline TW & \multicolumn{3}{|c|}{$* * *$} \\
\hline PE & \multicolumn{3}{|c|}{$* * *$} \\
\hline \multirow[t]{2}{*}{$\mathrm{TW} \times \mathrm{PE}$} & \multicolumn{3}{|c|}{$* * *$} \\
\hline & \multicolumn{3}{|c|}{ Snapdragon } \\
\hline Week 13 & $43 \mathrm{aC}$ & $69 \mathrm{aA}$ & $65 \mathrm{aB}$ \\
\hline Week 14 & $42 \mathrm{aB}$ & $59 \mathrm{bA}$ & $59 \mathrm{bA}$ \\
\hline Week 15 & $39 \mathrm{bB}$ & $53 \mathrm{cA}$ & $52 \mathrm{cA}$ \\
\hline \multicolumn{4}{|l|}{ Significance } \\
\hline TW & & $* * *$ & \\
\hline PE & & $* * *$ & \\
\hline $\mathrm{TW} \times \mathrm{PE}$ & & $* * *$ & \\
\hline
\end{tabular}

${ }^{\mathrm{z} W i t h i n-c o l u m n}$ means followed by different lower-case letters are significantly different by Tukey's honest significant difference (HSD) test at $P \leq 0.05$.

'Within-row means followed by different upper-case letters are significantly different by Tukey's HSD test at $P \leq 0.05$.

***Significant at $P \leq 0.001$.

Table 4. Expt. 1B Cornell University. Time to flower (TTF; days) from transplant to first open flower for dianthus, petunia, and snapdragon grown in three production environments; greenhouse $(\mathrm{GH})$, high tunnel $(\mathrm{HT})$, high tunnel + rowcover $(\mathrm{HT}+\mathrm{RC})$, transplanted during weeks 13,14 , and 15 . Means sharing a letter are not statistically different by Tukey's honestly significant difference test at $P \leq 0.05$.

\begin{tabular}{|c|c|c|c|}
\hline \multirow[b]{2}{*}{ Transplant week (TW) } & \multicolumn{3}{|c|}{ Production environment (PE) } \\
\hline & $\mathrm{GH}$ & HT & $\mathrm{HT}+\mathrm{RC}$ \\
\hline & \multicolumn{3}{|c|}{ Dianthus } \\
\hline Week 13 & $54 \mathrm{a}^{\mathrm{z}} \mathrm{A}^{\mathrm{y}}$ & $55 \mathrm{aA}$ & $56 \mathrm{aA}$ \\
\hline Week 14 & $51 \mathrm{abA}$ & $51 \mathrm{abA}$ & $50 \mathrm{abA}$ \\
\hline Week 15 & $46 \mathrm{bA}$ & $47 \mathrm{bA}$ & $45 \mathrm{bA}$ \\
\hline \multicolumn{4}{|l|}{ Significance } \\
\hline TW & \multicolumn{3}{|c|}{$* * *$} \\
\hline $\mathrm{PE}$ & \multicolumn{3}{|c|}{ NS } \\
\hline \multirow[t]{2}{*}{$\mathrm{TW} \times \mathrm{PE}$} & \multicolumn{3}{|c|}{ NS } \\
\hline & \multicolumn{3}{|c|}{ Petunia } \\
\hline Week 13 & $44 \mathrm{aB}$ & $51 \mathrm{aA}$ & $52 \mathrm{aA}$ \\
\hline Week 14 & $41 \mathrm{aB}$ & $46 \mathrm{bA}$ & $47 \mathrm{bA}$ \\
\hline Week 15 & $40 \mathrm{aB}$ & $44 \mathrm{bAB}$ & $45 \mathrm{bA}$ \\
\hline \multicolumn{4}{|l|}{ Significance } \\
\hline TW & & $* * *$ & \\
\hline PE & & $* * *$ & \\
\hline \multirow[t]{2}{*}{$\mathrm{TW} \times \mathrm{PE}$} & \multirow{2}{*}{\multicolumn{3}{|c|}{$\begin{array}{c}\text { NS } \\
\text { Snapdragon }\end{array}$}} \\
\hline & & & \\
\hline Week 13 & $50 \mathrm{aB}$ & $72 \mathrm{aA}$ & $74 \mathrm{aA}$ \\
\hline Week 14 & $47 \mathrm{abB}$ & $65 \mathrm{bA}$ & $66 \mathrm{bA}$ \\
\hline Week 15 & $45 \mathrm{bB}$ & $57 \mathrm{cA}$ & $58 \mathrm{cA}$ \\
\hline \multicolumn{4}{|l|}{ Significance } \\
\hline TW & & $* * *$ & \\
\hline $\mathrm{PE}$ & & $* * *$ & \\
\hline $\mathrm{TW} \times \mathrm{PE}$ & & $* * *$ & \\
\hline
\end{tabular}

$\overline{{ }^{z} W i t h i n-c o l u m n ~ m e a n s ~ f o l l o w e d ~ b y ~ d i f f e r e n t ~ l o w e r-c a s e ~ l e t t e r s ~ a r e ~ s i g n i f i c a n t l y ~ d i f f e r e n t ~ b y ~ T u k e y ' s ~}$ honest significant difference (HSD) test at $P \leq 0.05$.

${ }^{y}$ Within-row means followed by different upper-case letters are significantly different by Tukey's HSD test at $P \leq 0.05$.

*** Significant at $P \leq 0.001,{ }^{\mathrm{NS}}$ nonsignificant at $(P>0.05)$.

1 or 2 weeks before moving to the HT or $\mathrm{HT}+\mathrm{RC}$ did not significantly influence TTF compared with plants moved to the HT or $\mathrm{HT}+\mathrm{RC}$ directly after transplant (Figs. 1A and 2A). For petunia placed in the HT, TTF was delayed by $\approx 8 \mathrm{~d}$ at both locations compared with plants grown in the $\mathrm{GH}$ regardless if they were held in the GH for 0,1 , 


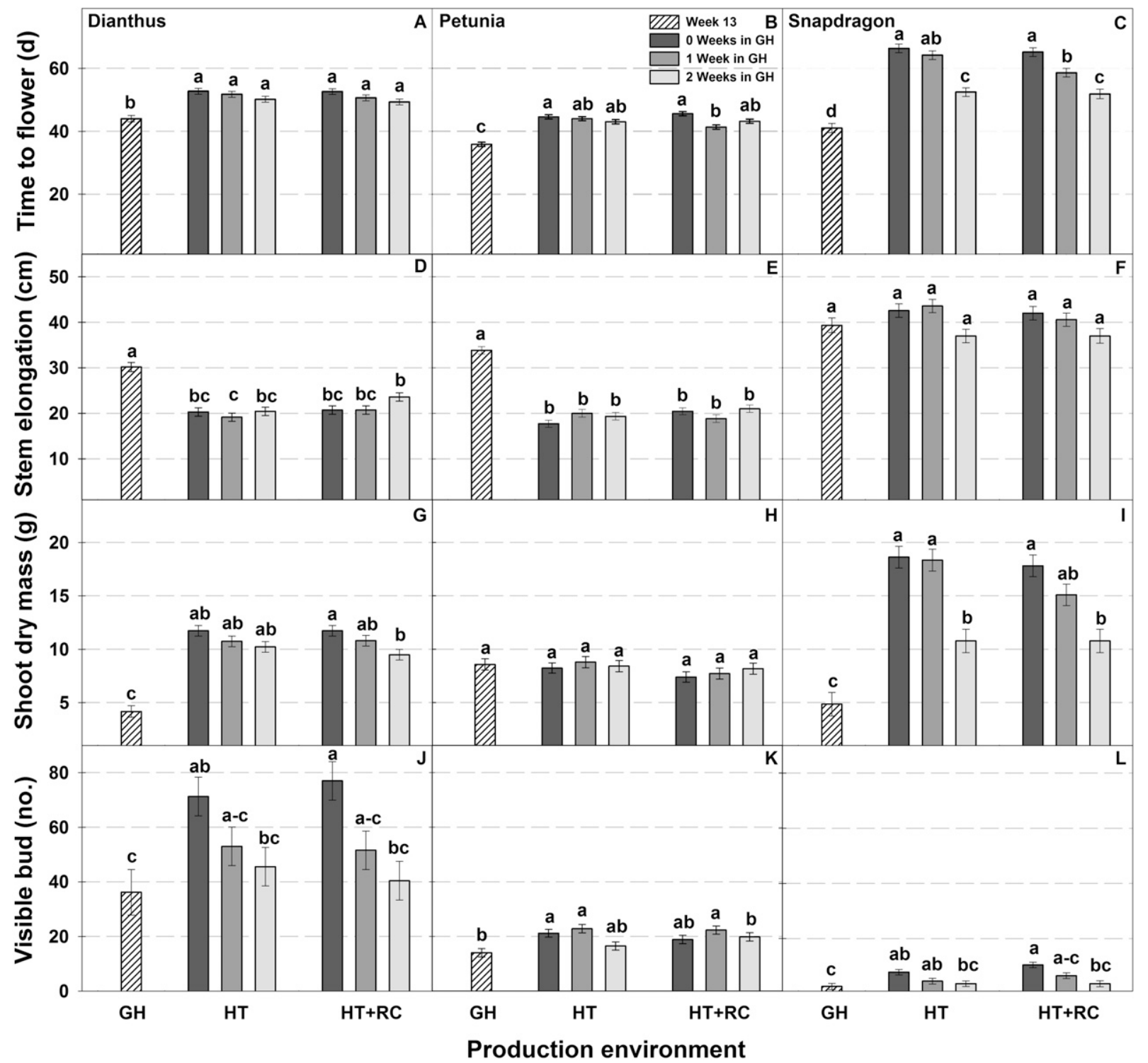

Fig. 1. Expt. 2A Purdue University. Time to flower (days), stem elongation (cm), shoot dry mass (g), and visible flower bud number (no.) for dianthus, petunia, and snapdragon grown in three production environments; greenhouse $(\mathrm{GH})$, high tunnel (HT), high tunnel + rowcover $(\mathrm{HT}+\mathrm{RC})$, held in the GH for 0,1 , and 2 weeks. Means sharing a letter are not statistically different by Tukey's honestly significant difference test at $P \leq 0.05$, error bars indicate \pm SE.

or 2 weeks (Figs. 1B and 2B). However, holding petunia in the greenhouse for 1 week (Purdue) or 2 weeks (Cornell) reduced TTF by $\approx 5 \mathrm{~d}$ as compared with plants held for 0 weeks if they were transplanted in the HT+RC. At both locations, snapdragon transplanted into the $\mathrm{HT}$ and $\mathrm{HT}+\mathrm{RC}$ after 0 weeks in the GH was delayed by 22 to $25 \mathrm{~d}$, compared with those grown in the $\mathrm{GH}$ (Figs. $1 \mathrm{C}$ and $2 \mathrm{C}$ ). At Purdue, holding snapdragon in the $\mathrm{GH}$ for 1 or 2 weeks reduced the delay in TTF for the HT or $\mathrm{HT}+\mathrm{RC}$ plants as compared with those held for 0 weeks before moving to the HT environment (Fig. 1C). There was some evidence for this pattern at Cornell but the reduction in TTF was not statistically significant (Fig. 2C). The modest reductions in TTF for petunia and snapdragon may not justify the added energy inputs needed to heat the GH for 1 or 2 weeks, making this production strategy of holding plants in the GH for early establishment in the HT not beneficial for energy savings. However, the overall response in both experiments reinforces the paradigm that TTF is a function of ADT, assuming other cultural and environmental factors are not limiting (Roberts and Summerfield, 1987).

Effects of transplant week and production environment on growth and morphology. Bedding plants are considered high-quality when they are compact (i.e., reduced stem elongation), fill the container (i.e., high shoot dry mass), are well branched, and have a high flower-bud count (Faust, 2011). Growers generally use chemical growth regulators to manage stem elongation to keep bedding plants compact; however, their use increases production costs. Temperature is another tool that growers can use to manipulate plant morphology to reduce stem elongation. In many plant species, stem elongation is influenced by the difference between the day and night temperatures, or DIF. Stem elongation is promoted when day temperatures are warmer than night temperatures (+DIF) and suppressed when day temperatures are cooler than night temperatures
(-DIF) (Erwin et al., 1989; Erwin and Hines, 1995; Kaczperski et al., 1991). The effects of cooler day temperatures to create a -DIF are generally perceived by plants $\approx 30 \mathrm{~min}$ before sunrise until about three hours after sunrise. This response has enabled growers to use a strategy called morning DIP or DROP. A DROP lowers the air temperature set point in the early morning period to simulate a cooler day, then raise the temperature in the late morning to increase the ADT (Blanchard and Runkle, 2011a).

In our study, stem elongation was often significantly less when plants were grown in the HT and HT+RC compared with the GH. Petunia at both locations, dianthus at Purdue, and snapdragon at Cornell had reduced stem elongation in the HT and $\mathrm{HT}+\mathrm{RC}$ environments as compared with their $\mathrm{GH}$ counterparts. For example, petunia transplanted at Purdue during week 13 in the HT and HT+RC were $47 \%$ and $43 \%$ shorter, respectively, than those in the GH (Fig. 3B). Similarly, petunia transplanted at Cornell during week 13 in the 


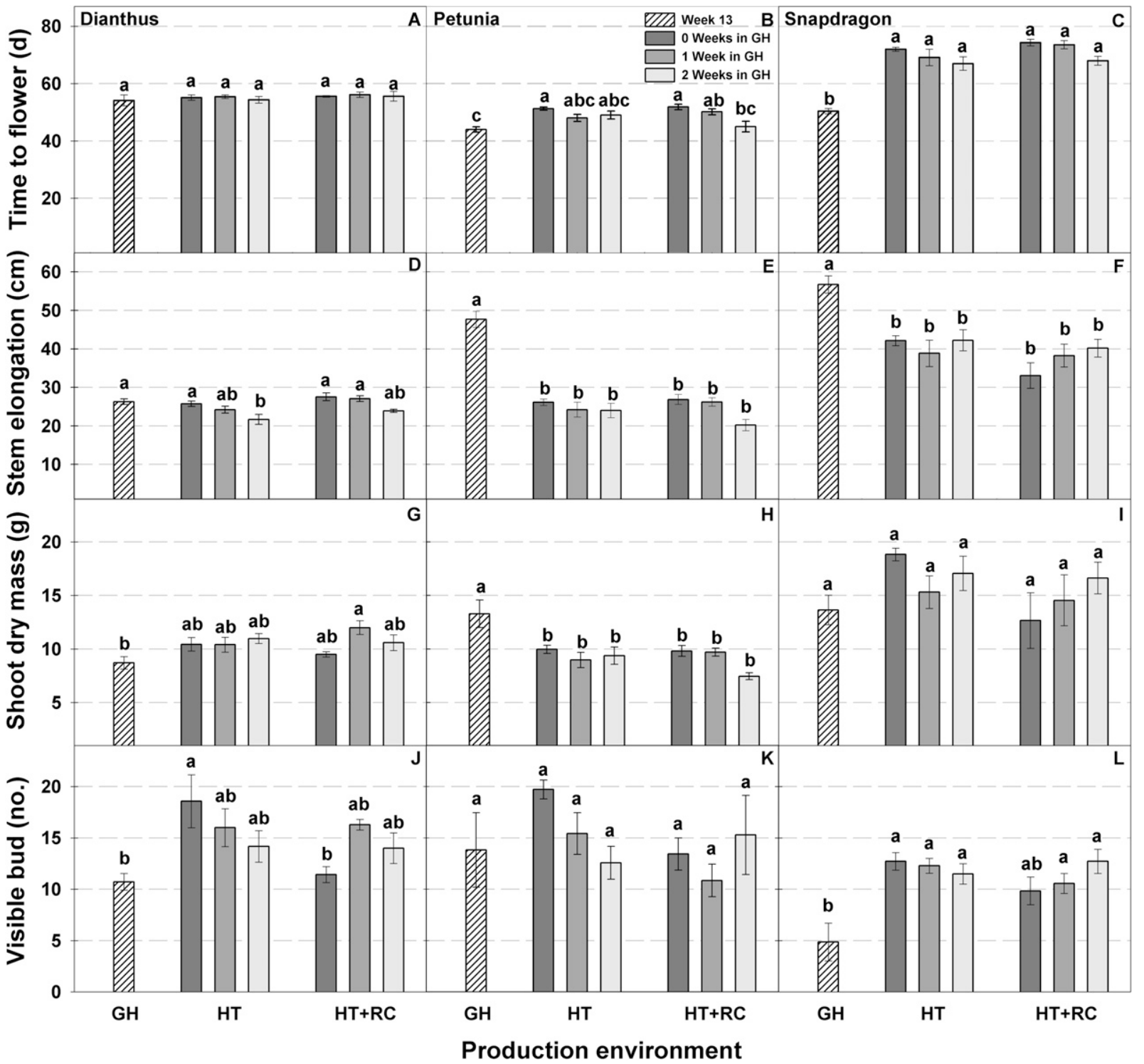

Fig. 2. Expt. $2 B$ Cornell University. Time to flower (days), stem elongation ( $\mathrm{cm})$, shoot dry mass $(\mathrm{g})$, and visible flower bud number (no.) for dianthus, petunia, and snapdragon grown in three production environments; greenhouse $(\mathrm{GH})$, high tunnel (HT), high tunnel + rowcover (HT+RC), held in the GH for 0, 1 , and 2 weeks. Means sharing a letter are not statistically different by Tukey's honestly significant difference test at $P \leq 0.05$, error bars indicate \pm SE.

HT and $\mathrm{HT}+\mathrm{RC}$ were $45 \%$ and $43 \%$ shorter, respectively, than their GH counterparts (Fig. 4B). At Purdue, dianthus transplanted during week 13 in the $\mathrm{HT}$ and $\mathrm{HT}+\mathrm{RC}$ were $33 \%$ and $35 \%$ shorter, respectively, than those in the GH (Fig. 3A). At Cornell, snapdragon stem elongation was reduced by about $30 \%$ when plants were grown in the HT or $\mathrm{HT}+\mathrm{RC}$ as compared with the $\mathrm{GH}$ regardless of transplant week (Fig. 4C).

In some cases stem elongation was significantly influenced by transplant week. Transplant week had a significant impact on stem elongation in the GH for dianthus and petunia at Purdue. Specifically, dianthus transplanted during week 15 were $12 \%$ shorter than those transplanted during week 13 , and petunia transplanted during week 15 were $12 \%$ shorter than those transplanted during week 14 (Fig. 3A and B). At Cornell, HT+RC dianthus transplanted during week 15 were $24 \%$ shorter than those transplanted during week 13 (Fig. 4A). Greenhouse petunia at Cornell were $19 \%$ shorter when transplanted at week 14 vs. week 13 . The inhibition in stem elongation in the later transplant weeks for dianthus and petunia was likely affected by the increase in DLI as the spring progressed (Tables 1 and 2).

For Expt. 2 at Purdue, HT and $\mathrm{HT}+\mathrm{RC}$ dianthus and petunia held in the $\mathrm{GH}$ for 0,1 , or 2 weeks were significantly shorter than their counterparts finished solely in the GH (Fig. 1D and E). For Expt. 2 at Cornell, dianthus moved to the HT after 2 weeks were significantly shorter than their counterparts finished solely in the GH (Fig. 2D). GH-grown petunia at Cornell were about twice the height as their counterparts finished under HT and HT $+\mathrm{RC}$, regardless of whether they were held in the GH for 0,1 , or 2 weeks (Fig. 2E). Similarly, although the magnitude of stem elongation response was not as large, $\mathrm{HT}$ and $\mathrm{HT}+\mathrm{RC}$ snapdragon were significantly shorter than their GH counterparts (Fig. 2F).

While our results appear to contradict the concept of DIF to control stem elongation it should be noted that the majority of studies conducted to determine effects of DIF were performed in controlled environments, where temperatures were highly regulated (Erwin et al., 1989; Kaczperski et al., 1991) as compared with the highly variable temperatures in the HT in the present study. We expected the large +DIF in the HT (Table 1) to promote stem elongation. An HT experiences large diurnal temperature fluctuations, which makes it difficult to compare our results to ones that were completed in controlled environments. Currey et al. (2014) reported similar reductions in stem elongation in several HT-grown bedding plant species when compared with that in a conventional GH. Their lowest nighttime temperature generally occurred predawn, and the authors suggested that this temperature regimen may have created a temperature DROP effect, which can create a-DIF response (Currey et al., 2014). We experienced similar trends in our HT and postulate that cool 


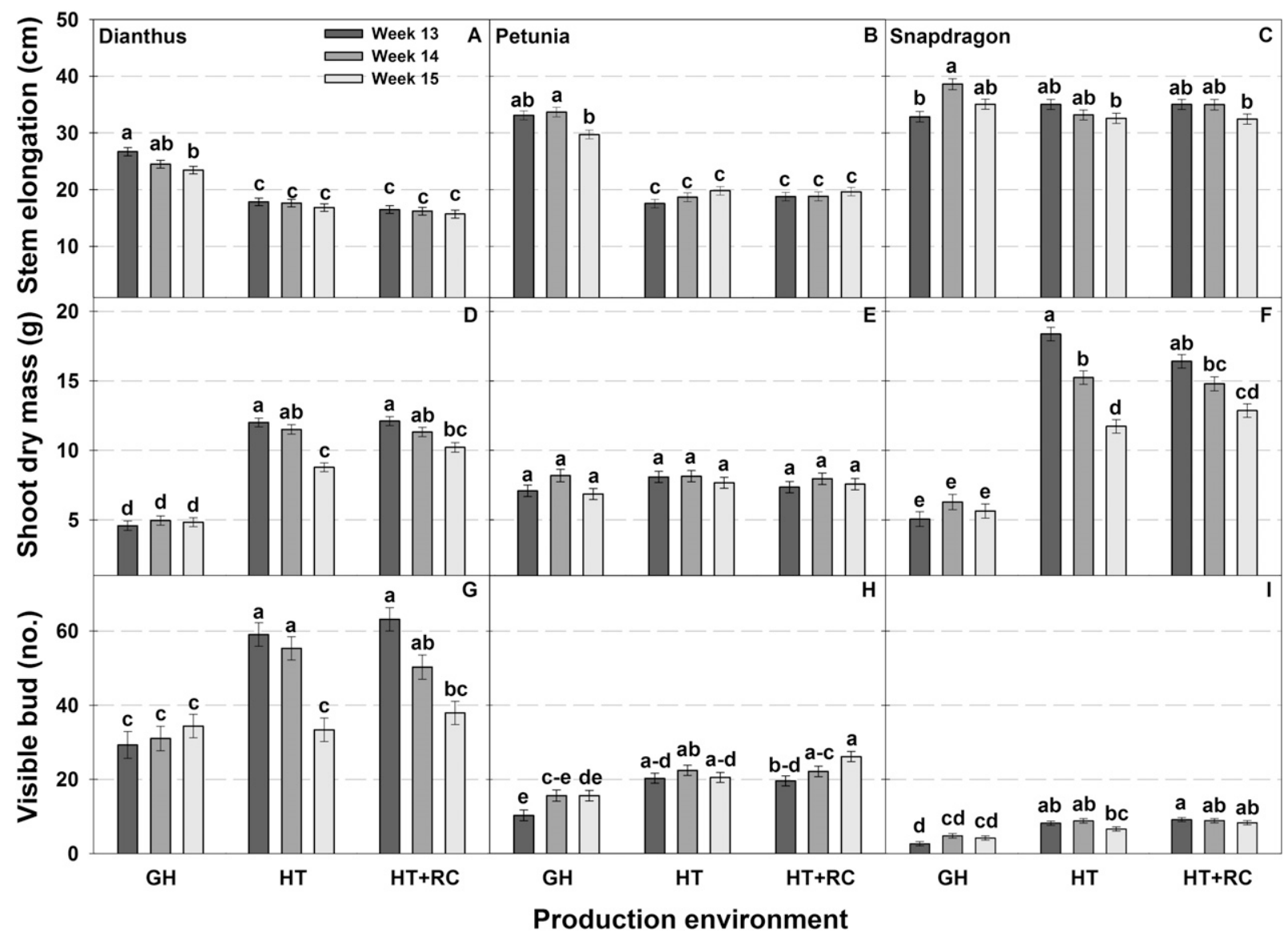

Fig. 3. Expt. 1A Purdue University. Stem elongation (cm), shoot dry mass (g), and visible flower bud number (no.) or dianthus, petunia, and snapdragon grown in three production environments; greenhouse $(\mathrm{GH})$, high tunnel (HT), high tunnel + rowcover (HT+RC), transplanted during weeks 13, 14, and 15. Means sharing a letter are not statistically different by Tukey's honestly significant difference test at $P \leq 0.05$, error bars indicate \pm SE.

morning temperatures may have led to the suppression in stem elongation of petunia and dianthus grown in the HT.

Additionally, we postulate that suppression of stem elongation in the HT was influenced by the higher DLI. Increasing DLI has been shown to reduce stem elongation, during both constant and diurnal temperatures regimens (Faust et al., 2005; Kaczperski et al., 1991). For example, plant height of 'Snow Cloud' petunia grown at a constant air temperature of $15{ }^{\circ} \mathrm{C}$ was reduced by $32 \%$ as DLI increased from 6.5 to $13 \mathrm{~mol} \cdot \mathrm{m}^{-2} \cdot \mathrm{d}^{-1}$. Additionally, plant height for petunia grown with a diurnal day/night temperature of $20 / 15^{\circ} \mathrm{C}$ was reduced by $29 \%$ as DLI increased from 6.5 to $13 \mathrm{~mol} \cdot \mathrm{m}^{-2} \cdot \mathrm{d}^{-1}$ (Kaczperski et al., 1991). Increasing the DLI has also been shown to increase the number of lateral shoots of many bedding plant species (Faust, 2011). We did not quantify the number of lateral shoots, but plants grown in the HT had more lateral branches (data not shown) than those grown in the GH. Increased lateral branching results in a reduction of stem elongation and could further explain the reduced stem elongation in the HT.

It is well established that increasing DLI generally increases biomass accumulation (Faust et al., 2005; Heins et al., 2000; Kaczperski et al., 1991). High shoot dry mass (along with a compact plant form) is a desirable quality trait as it can serve as one quantitative measure of how well a plant has "filled out" a container. At Purdue, where the HT and $\mathrm{HT}+\mathrm{RC}$ environments had much greater DLI than the $\mathrm{GH}$, the shoot dry mass of dianthus and snapdragon was significantly greater when they were grown in the $\mathrm{HT}$ and $\mathrm{HT}+\mathrm{RC}$ compared with the $\mathrm{GH}$, regardless of transplant week. Shoot dry mass was also influenced by transplant week. For example, dianthus at Purdue transplanted in week 13 in the HT and HT+RC had a $27 \%$ and $16 \%$ increase in shoot dry mass, respectively, than those transplanted in week 15 (Fig. 3D). Additionally, snapdragon transplanted at Purdue during week 13 in the $\mathrm{HT}$ and $\mathrm{HT}+\mathrm{RC}$ had a $37 \%$ and $21 \%$ increase in shoot dry mass, respectively, than those transplanted in week 15 (Fig. 3F). Similarly at Cornell, HT snapdragon transplanted during week 13 had a $28 \%$ increase in shoot dry mass than plants transplanted on week 15 (Fig. 4F).

For Expt. 2 at Purdue, HT and HT+RC dianthus exhibited greater shoot dry mass regardless of whether they were held for 0 , 1 , or 2 weeks in the $\mathrm{GH}$ as compared with their counterparts finished solely in the GH (Fig. 1G). Additionally, snapdragon exhibited a similar positive shoot dry mass response to the HT and HT+RC environment, although the effect was reduced the longer the plants were held in the GH (Fig. 1I). Shoot dry mass of petunia in Expt. 2 at Purdue did not respond to $\mathrm{HT}$ or $\mathrm{HT}+\mathrm{RC}$ treatment (Fig. $1 \mathrm{H})$. At
Cornell, dianthus in Expt. 2 had a greater shoot dry mass than GH only plants when held in the greenhouse for 1 week before moving to $\mathrm{HT}+\mathrm{RC}$ (Fig. 2G). Petunia in the $\mathrm{HT}$ and $\mathrm{HT}+\mathrm{RC}$ treatment at Cornell had reduced shoot dry mass regardless of whether they were held in the GH for 0,1 , or 2 weeks as compared with their GH only counterparts (Fig. 2H). Shoot dry mass of snapdragon were not significantly affected by HT or HT + RC treatment at Cornell (Fig. 2I).

Plant growth, defined as an irreversible increase in plant size, is a function of biomass production driven by photosynthesis (Heins et al., 2000). Decreased ADT increases time to flower so plants have more time to accumulate light and hence biomass (Blanchard et al., 2011). Therefore, we believe the lengthened production time for some HT plants as well as increased DLI were responsible for the increased shoot dry mass for dianthus and snapdragon (Table 1).

High visible flower bud count is considered one of the primary factors of high-quality associated with marketing bedding plants (Faust, 2011) as visible buds contribute to floral display in the retail/consumer environment. Reduced air temperatures and increased DLI generally increases flower number and size in shade-avoiding plants (Heins et al., 2000). At Purdue, visible bud number was significantly greater in the $\mathrm{HT}$ and $\mathrm{HT}+\mathrm{RC}$ production environments for dianthus and 


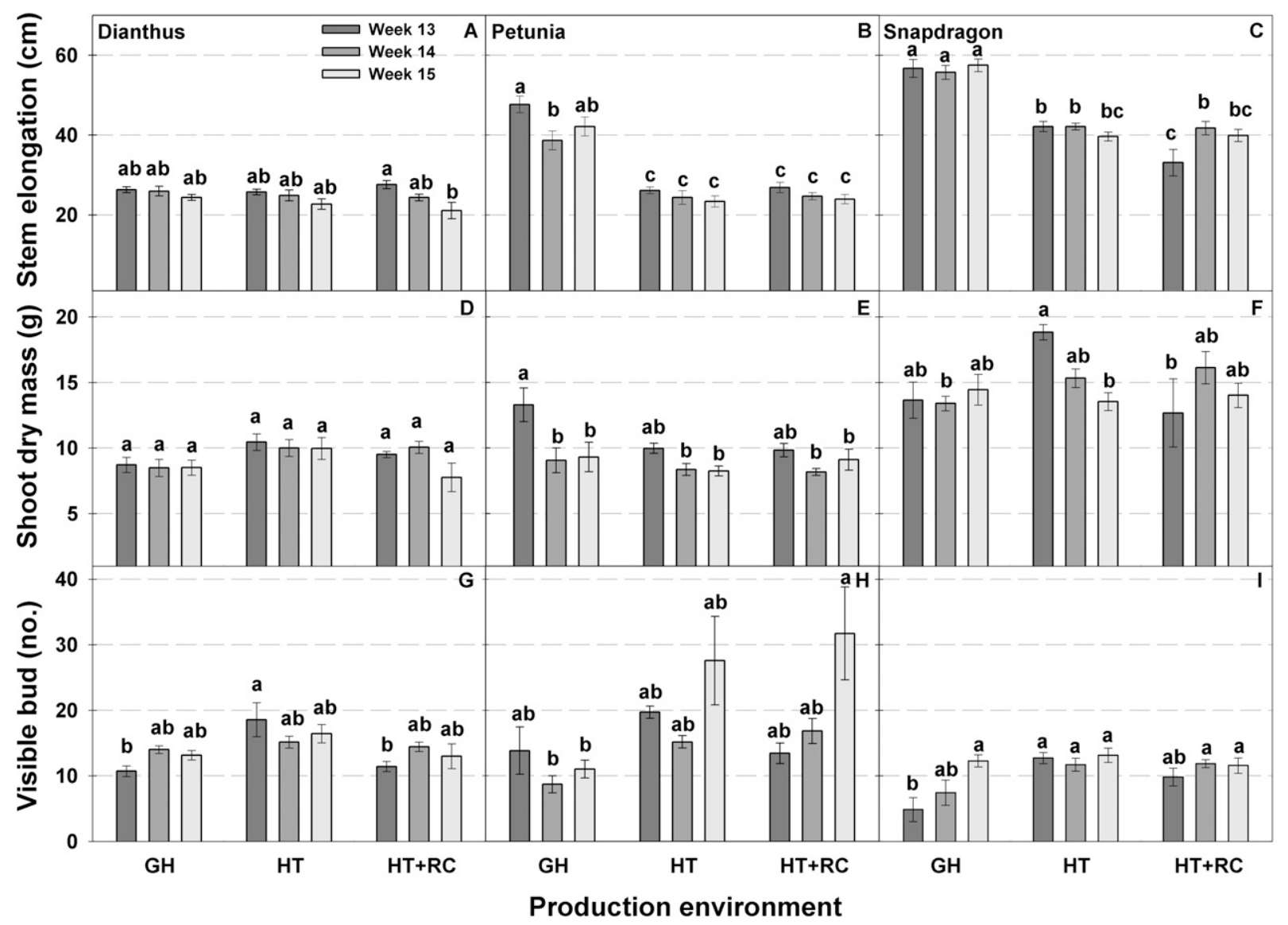

Fig. 4. Expt. 1B Cornell University. Stem elongation (cm), shoot dry mass (g), and visible flower bud number (no.) for dianthus, petunia, and snapdragon grown in three production environments; greenhouse $(\mathrm{GH})$, high tunnel $(\mathrm{HT})$, high tunnel + rowcover $(\mathrm{HT}+\mathrm{RC})$, transplanted during weeks 13 , 14, and 15. Means sharing a letter are not statistically different by Tukey's honestly significant difference test at $P \leq 0.05$, error bars indicate \pm SE.

snapdragon transplanted in week 13 and 14 and petunia transplanted week 13 compared with the GH (Fig. 3G-I). For example, visible flower bud number of dianthus increased $51 \%$ and $41 \%$ in the HT and $54 \%$ and $38 \%$ in the HT+RC in week 13 and 14 , respectively, when compared with the $\mathrm{GH}$ (Fig. 3G). However, there were no significant differences for HT and HT + RC production environments transplanted in week 15 compared with those in the GH (Fig. 3G and $\mathrm{H})$. For Purdue snapdragon, visible flower bud number increased $68 \%$ and $71 \%$ in the HT and HT+RC for plants transplanted in week 13 , respectively, when compared with the GH (Fig. 1J). At Cornell, trends in visible flower bud number between $\mathrm{GH}, \mathrm{HT}$, or $\mathrm{HT}+\mathrm{RC}$ were a bit less dramatic, likely due to less differences in DLI than at Purdue (Table 2). At Cornell, HT benefits on visible flower buds was most evident at week 13. At Cornell, HT dianthus transplanted week 13 had a $73 \%$ increase in visible flower bud vs. their GH or HT+RC counterparts (Fig. 4G). Snapdragon at Cornell transplanted in week 13 had a $160 \%$ increase in visible flower buds when finished in the HT vs. the GH (Fig. 4I).

At Purdue, visible bud number of dianthus in Expt. 2 was significantly greater for HT/ $\mathrm{HT}+\mathrm{RC}$ plants held in the GH for 0 weeks as compared with plants finished solely in the GH (Fig. 1J). Petunia moved to the HT after
0 or 1 weeks or to HT+RC after 1 week had more visible buds than their GH counterparts (Fig. 1K). Similarly snapdragon moved to the HT at 0 or 1 week or to HT+RC after 0 week had more visible buds than plants finished in the GH only (Fig. 1L). At Cornell, dianthus in Expt. 2 that were moved to the HT after 0 week had $64 \%$ more visible buds than their GH only counterparts (Fig. 2J). Visible bud of petunia in Expt. 2 were unaffected by HT/ $\mathrm{HT}+\mathrm{RC}$ treatment (Fig. 2K). Snapdragon in Expt. 2 had more visible buds when moved to the HT after 0,1 , or 2 weeks or to $\mathrm{HT}+\mathrm{RC}$ after 1 or 2 weeks as compared with their GH only counterparts (Fig. 2J).

Collectively our findings indicate that in several cases the cool, high-light environment (Tables 1 and 2) of the HT, whereas delaying TTF, can contribute to higher quality bedding plants by reducing stem elongation, increasing shoot dry mass, and increasing visible flower bud number. Similarly, in a controlled greenhouse experiment number of visible buds at flowering for petunia 'Easy Wave Coral Reef' and 'Wave Purple' increased as ADT was decreased from 26 to $14{ }^{\circ} \mathrm{C}$ and DLI increased from 4 to $19 \mathrm{~mol} \cdot \mathrm{m}^{-2} \cdot \mathrm{d}^{-1}$ (Blanchard and Runkle, 2011a). Increased visible flower number may be due, in part, to increased lateral branching under low ADT, as reported for petunia 'Dreams Rose' by Mattson and Erwin
(2003). In several cases, response to production environment differed between the three crops investigated in our study. This was expected as plant growth and TTF response to light and temperature are well known to vary according to plant species and cultivar (Blanchard and Runkle, 2011b; Faust et al., 2005; Mattson and Erwin, 2005).

\section{Conclusion}

In summary, our findings demonstrate that cold-tolerant bedding plants can be successfully finished in an HT environment at two different northern latitude locations. Overall, plant quality, in terms of reduced stem elongation and increased shoot dry mass and visible flower bud number, was significantly improved in an HT as compared with the GH although results varied based on species, location, and transplant week. A negative consequence of HT production was delayed flowering especially in snapdragon. Waiting to transplant and move to the HT until weeks 14 or 15 can partially ameliorate the delays in flowering exhibited by plants moved into the HT on week 13 . While the RC increased minimum night temperature it did not have a major effect on crop quality, perhaps because extreme low temperature events were not encountered in 2012 or 2013 . Holding bedding plants in the 
GH before moving to the HT growing environment did not significantly reduce TTF in most cases and thus may not be an energyefficient practice. While the HT environment can be successfully used to finish highquality bedding plants, it can be risky due to losses from extreme outdoor temperature fluctuations. Growers can mitigate this risk by holding transplants in a $\mathrm{GH}$ temporarily, use of RC, and having emergency heating available.

\section{Literature Cited}

Adams, S.R., P. Hadley, and S. Pearson. 1998. The effects of temperature, photoperiod, and photosynthetic photon flux on the time to flowering of petunia 'Express Blush Pink'. J. Amer. Soc. Hort. Sci. 123:577-580.

Blanchard, M. and E. Runkle. 2011a. Temperature, p. 67-81. In: J. Nau (ed.). Ball redbook, Vol. II, 18th ed. Ball Publishing, West Chicago, IL.

Blanchard, M.G. and E.S. Runkle. 2011b. Quantifying the thermal flowering rates of eighteen species of annual bedding plants. Sci. Hort. 128:30-37.

Blanchard, M.G., E.S. Runkle, and P.R. Fisher. 2011. Modeling plant morphology and development of petunia in response to temperature and photosynthetic daily light integral. Sci. Hort. 129:313-320.

Brumfield, R.G., A.J. Both, and G. Wulster. 2009. How are greenhouse growers coping with rising energy costs? Rutgers Farm Manage. Newsl. 9(2):1-4.

Currey, C.J., R.G. Lopez, and N.S. Mattson. 2014. Finishing bedding plants: A comparison of an unheated high tunnel versus a heated greenhouse in two geographic locations. HortTechnology 24:527-534.

Energy Information Administration (EIA). 2014. Natural gas prices. U.S. Energy Information Admin., Washington, DC. 10 May 2014. $<$ http://www.eia.gov/dnav/ng/ng_pri_sum_ dcu_nus_m.htm>.

Erwin, J.E. and R.D. Heins. 1995. Thermomorphogenic responses in stem and leaf development. HortScience 30:940-949.

Erwin, J.E., R.D. Heins, and M.G. Karlsson. 1989. Thermomorphogenesis in Lilium longiflorum. Amer. J. Bot. 76:47-52.

Faust, J.E. 2011. Light, p. 83-94. In: J. Nau (ed.). Ball redbook, Vol. II, 18th ed. Ball Publishing, West Chicago, IL.

Faust, J.E., V. Holcombe, N.C. Rajapaske, and D.R. Layne. 2005. The effect of daily light integral on bedding plant growth and flowering. HortScience 403:645-649.

Heins, R.D., B. Liu, and E.S. Runkle. 2000. Regulation of crop growth and development based on environmental factors. Acta Hort. 511:13-22.

Hunter, B., D. Drost, and B. Black. 2012. Improving growth and productivity of early-season high-tunnel tomatoes with targeted temperature additions. HortScience 47:733-740.

Kaczperski, M.P., W.H. Carlson, and M.G. Karlsson. 1991. Growth and development of Petunia $\times$ hybrida as a function of temperature and irradiance. J. Amer. Soc. Hort. Sci. 116:232-237.

Knewtson, S.J.B., E.E. Carey, and M.B. Kirkham. 2010. Management practices of growers using high tunnels in the central great plains of the United States. HortTechnology 20:639-645.
Langton, A., C. Plackett, and H. Kitchener. 2006. Energy saving in poinsettia production. Hort. Dev. Council Factsheet 7:1-12.

Lamont, W.J. 2005. Plastics: Modifying the microclimate for the production of vegetable crops. HortTechnology 15:477-481.

Lamont, W.J. 2009. Overview of the use of high tunnels worldwide. HortTechnology 19:25-29.

Mattson, N. and J. Erwin. 2003. Temperature affects flower initiation and development rate of Impatiens, Petunia, and Viola. Acta Hort. 624:191-197.

Mattson, N.S. and J.E. Erwin. 2005. The impact of photoperiod and irradiance on flowering of several herbaceous ornamentals. Sci. Hort. 104:275-292.

Ortiz, M.A., K. Hyrczyk, and R.G. Lopez. 2012. Comparison of high tunnel and field production of specialty cut flowers in the Midwest. HortScience 47:1265-1269.

Roberts, E.H. and R.J. Summerfield. 1987. Measurement and prediction of flowering in annual crops, p. 17-50. In: J.G. Atherton (ed.). Manipulation of flowering. Butterworths, London, UK.

Rowley, D., B.L. Black, and D. Drost. 2010. Earlyseason extension using June-bearing 'Chandler' strawberry in high-elevation high tunnels. HortScience 45:1464-1469.

United States Department of Agriculture (USDA). 2014. Census of agriculture. 10 May 2014. $<$ http://www.agcensus.usda.gov/Publications/ 2012/Full_Report/Volume_1,_Chapter_1_US/ st99_1_041_042.pdf >.

Vaid, T.M. and E.S. Runkle. 2013. Developing flowering rate models in response to mean temperature for common annual ornamental crops. Sci. Hort. 161:15-23. 